\title{
Beneficial Effect Administration of Vitamin C in Amelioration of Lead Hepatotoxicity
}

\author{
Nadia AIT HAMADOUCHE, Miloud SLIMANI, Abdelkader AOUES \\ University Es-senia, Department of Biology, Laboratory of Experimental Biotoxicology, \\ Biodepollution and Phytoremediation, Oran, Algeria; naithamadouche@live.fr
}

\begin{abstract}
Previous human and experimental studies have demonstrated that lead exposure may modify the metabolism of lipid. Oxidative stress with subsequent lipid peroxidation has been postulated as one mechanism for lead toxicity. The protective action of vitamins $\mathrm{C}$ against lead affects lipid hydroperoxide level and liver functions in male rats has been studied. Experiments were performed on male waster rats with body weights of 120-160 g. Male wistar rats were exposed to $3 \mathrm{~g} / \mathrm{l}$ lead acetate in drinking water for 5 weeks and treated thereafter with vitamin C ( $500 \mathrm{mg} / \mathrm{kg}$, orally) for 28 days. One day after the feeding was over, venous blood samples, under chloroform anesthesia, were collected. The animals were killed by exsanguinations and the liver was excise for determination the metal content and histopathological changes. Similarly, the tissue lipid (lipid peroxidation) and the enzyme fraction (superoxide dismutase (SOD), catalase (CAT), alkaline phosphatase (ALP), acid phosphatase (ACP) and glutathione (GSH) were also measured in the liver. Metal content in blood and liver was determined by means of atomic absorption spectrophotometry. Administration of lead acetate (3 g/l) in drinking water for 5 weeks induced a significant increase in the levels of hepatic ALP, ACP and lipid peroxidation. Lead acetate exposure also produced detrimental effects on the redox status of the liver indicated by a significant decline in the levels of liver antioxidants such SOD, CAT and GSH. Further, there was a significant $(p<0.001)$ increase in the levels of lead in blood and liver of animals exposed to lead. However, oral administration of vitamin C at dose level of $500 \mathrm{mg} / \mathrm{kg}$ body weight reduced the alterations in the previous parameters. Histological examination of the liver also revealed pathophysiological changes in lead acetate-exposed group and treatment with vitamin $\mathrm{C}$ improved liver histology. The result of this study strongly indicate that vitamin $\mathrm{C}$ has got a potent antioxidant action against lead acetate induced hepatic damage in rats.
\end{abstract}

Keywords: lead, lipid peroxidation, rats, superoxide dismutase, vitamin C

\section{Introduction}

Environmental pollution is the presence of a pollutant in environment such as air, water, soil and consequently in food which may be poisonous or toxic and will cause harm to living things in the polluted environment (Duruibe et al., 2007). The excessive amount of pollutants such as heavy metals in animal feed and feed stuffs are often due to human actions, resulting from either agricultural or industrial production or accidental or deliberate misuse (Aboul-Enein et al., 2010; Mohamed et al., 2009). There are at least 18 elements that characterize one or more inorganic pesticides. Of these elements, eight (barium, cadmium, mercury, thallium, lead, bismuth, antimony and boron) have not been shown to be essential to the growth of animals (El-Beltagi et al., 2010). In the instances, a series of elements, such as the heavy metal have been considered in the order of their atomic number. The definition of a heavy metal is one that a specific gravity of more than $5 \mathrm{~g} /$ $\mathrm{cm}^{3}$. By definition this would account for 60 metals several of which are biologically essential and many other lack sufficient information regarding toxicity including platinum, silver and gold. This arrangement of the elements helps to explain the chemistry and toxicology of their compound (Omaya, 2004). Many heavy metals, including Pb, are known to induce over production of reactive oxygen species (ROS) and consequently enhance lipid peroxidation, decrease the saturated fatty acids and increase the unsaturated fatty acid contents of membranes (Afify and El-Beltagi, 2011). Also, it has been shown to enhance the production of ROS in a variety of cells resulting oxidative stress (Hayes and Laws, 1991). ROS are the byproducts of many degenerative reactions in many tissues, which will affect the regular metabolism by damaging the cellular components (Malecka et al., 2001). Extensive study on oxidative stress has demonstrated that exposure of cells to adverse environmental conditions can induce the over production of ROS, such as superoxide radical $\left(\mathrm{O}^{-}\right), \mathrm{H}_{2}$ $\mathrm{O}_{2}$ and hydroxyl radical $\left(\mathrm{OH}^{-}\right)$in plant cells (Xienia et al., 2000). In addition, ROS are highly reactive to membrane lipids, protein and DNA. They are believed to be the major contributing factors to stress injuries and to cause rapid cellular damage (El-Beltagi et al., 2008; 2011). Traces of lead occur in many rocks in addition to those that are qualified as over lead, thus it can find its way into 
8

soil and water and hence into food, animals and human tissues even in remote places where there is no use of the metal or its compounds. In spite of its widespread distribution in tissues, there is no indication of no beneficial effect, but it causes many problems to the plant, food industry and animal health. Although various countries have established legislation regulating their concentration, they are still sometimes a danger for consumer health (El-Beltagi et al., 2008). Lead is translocated through the food chain to man and animals, its toxicity depends on its chemical from administrated to the animal, the route of administration and the frequency and duration administered to animals (Baht and Moy, 1977). Lead can affect individuals of any age, but it has a disproportionate effect on children because their behavioral patterns place them at higher risk for exposure to lead. Their bodies absorb a larger percentage of the lead that they ingest and they exhibit lead toxicity at lower level for exposure than adults (Baht and Moy, 1977). Accumulation of lead produces damaging effects in the hematopoetical, hematic, renal and gastrointestinal system (Correia et al., 2000). Liver is a frequent target for many toxicants (Meyer and Kulkarni, 2001). Autopsy studies of lead-exposed humans indicate that among soft tissue, liver is the largest repository (33\%) of lead, followed by kidney. Lead-induced hepatic damage is mostly rooted in lipid peroxidation (LPO) and disturbance of the prooxidant-antioxidant balance by generation of reactive oxygen species (ROS) (Bechara, 2004; Gurer and Ercal, 2000). Vitamin C (ascorbic acid), a water soluble vitamin is derived from dietary sources such as citrus fruits, grape-fruits, berries, cabbage, tomatoes, pepper and leafy vegetables. The therapeutic potential of vitamin $C$ is as a result of its antioxidant effect on free-radicals (Adaramoye et al., 2008). The aim of this study was to determine the effect of vitamin $\mathrm{C}$ on hepatotoxic effect caused by lead acetate in rats.

\section{Materials and methods}

\section{Animals}

Four-Five weeks old male albinos wistar rats were purchase from the Pasteur Institute in Algiers, Algeria. Rats weighing (120-160 g) were maintained under standard conditions of humidity temperature $\left(28 \pm 2^{\circ} \mathrm{C}\right)$ and light $(12 \mathrm{~h}$ light/dark). All the procedure performed on animals were approved and conducted in accordance with the $\mathrm{Na}$ tional Institute of health Guide (Reg. No. 488/160/1999/ CPCSEA).

\section{Experimental design}

The rats were divided into three groups 10 rat each:

Group A: Control rats were drinking distilled water.

Group B: Received $3 \mathrm{~g} / \mathrm{l}$ of lead acetate daily by oral administration for 28 days.

Group C: Received $3 \mathrm{~g} / \mathrm{l}$ of lead acetate and $500 \mathrm{mg} /$ $\mathrm{kg}$ body weight of vitamin $\mathrm{C}$ daily by oral administration for 28 days.
At the end of experience, all animals were fasted overnight; they were killed under light ether anesthesia. Livers were removed immediately, rinsed in ice-cold saline, histological studies, and used for various biochemical assays, histological studies, and determination of lead concentration.

\section{Biochemical assays}

Liver was minced and homogenized $(10 \% \mathrm{w} / \mathrm{v})$ in ice-cold 0.1 M sodium phosphate buffer ( $\mathrm{pH} 7.4)$. The homogenate was centrifuged at $10.000 \mathrm{rpm}$ for $15-20$ min at $4^{\circ} \mathrm{C}$ twice to get the enzyme fraction (superoxide dismutase (SOD), catalase (CAT), alkaline phosphatase (ALP), acid phosphatase (ACP) and glutathione (GHS). The supernatant was used for biochemical assays.

\section{Superoxide dismutase (SOD)}

Hepatic SOD activity was assayed according to the method of Marklund and Marklund (1974).

For the control, $0.1 \mathrm{ml}$ of $20 \mathrm{mM}$ pyrogallol solution was added to $2.9 \mathrm{ml}$ of Tris buffer and mixed, and reading was taken at $420 \mathrm{~nm}$ after 1.5 and 3.5 mins. The absorbance difference for 2 min was recorded and the concentration of pyrogallol was adjusted in such a way that the rate in change of absorbance per $2 \mathrm{~min}$ was approximately 0.020-0.023 optical density units.

Liver extract $(200 \mu \mathrm{l})$ was treated with $10 \mu \mathrm{l}$ of $25 \%$ triton X-100 and kept at $30^{\circ} \mathrm{C}$ for $30 \mathrm{~min}$. To $2.8 \mathrm{ml}$ of Tris buffer, $0.1 \mathrm{ml}$ of treated sample was added and mixed, and the reaction was started by adding $0.1 \mathrm{ml}$ of adjusted pyrogallol solution (as for control). Reading was taken at $420 \mathrm{~nm}$ after 1.5 and $3.5 \mathrm{mins}$ and the difference in absorbance was recorded. The enzyme activity was expressed as $\mathrm{U} / \mathrm{ml}$ of liver extract and $1 \mathrm{U}$ of enzyme is defined as the enzyme activity that inhibits auto-oxidation of pyrogallol by $50 \%$.

\section{Catalase}

Catalase (CAT) activity was estimated following the method of Aebi (1993). Liver extract (100 $\mu$ l) was treated with ethanol $(10 \mu \mathrm{l})$ and placed on an ice bath for $30 \mathrm{mn}$. To this, $10 \mu \mathrm{l}$ of $25 \%$ triton X-100 was added and again kept for $30 \mathrm{~min}$ on ice. To $200 \mu \mathrm{l}$ phosphate buffer $(0.1 \mathrm{M})$, $50 \mu \mathrm{l}$ of treated liver extract and $250 \mu \mathrm{l} \mathrm{of} 0.066 \mathrm{M} \mathrm{H}_{2} \mathrm{O}_{2}$ (prepared in $0.1 \mathrm{M}$ phosphate buffer, $\mathrm{pH}$ 7.0) were added in a cuvette. The decrease in optical density was measured at $240 \mathrm{~nm}$ for $60 \mathrm{~s}$. The molar extinction coefficient of $43.6 \mathrm{~cm}^{-1}$ was used to determine CAT activity. One unit of activity is equal to the moles of $\mathrm{H}_{2} \mathrm{O}_{2}$ degraded $/ \mathrm{min} /$ mg protein.

\section{Glutathione (GSH)}

Reducedglutathione was determined by the method of Ellman (1959). In brief, $1 \mathrm{ml}$ of supernatant was taken after precipitating $0.5 \mathrm{ml}$ of liver homogenate with $2 \mathrm{ml}$ of $5 \%$ TCA. To this, $0.5 \mathrm{ml}$ of Ellman's reagent $(0.019$ 
$\%$ DTNB in $1 \%$ sodium citrate) and $3 \mathrm{ml}$ of phosphate buffer ( $1 \mathrm{M}, \mathrm{pH}$ 8.0) was added. The color developed was read at $412 \mathrm{~nm}$. Reduced GSH concentration is measured by using a drawn standard curve and expressed as $\mathrm{mg} / \mathrm{g}$ of tissue.

\section{Acid phosphatase (ACP) and alkaline phosphatase (ALP)}

Activities of acid phosphatase and alkaline phosphatase were determined according to Sdashivam and Manickam (1996). Substrate solution $(3 \mathrm{ml})$ was incubated at $37^{\circ} \mathrm{C}$ for $15 \mathrm{~min}$ and then $0.5 \mathrm{ml}$ liver homogenate was added. It was mixed well and immediately $0.05 \mathrm{ml}$ of mixture was removed and mixed with $9.5 \mathrm{ml}$ of $0.085 \mathrm{~N} \mathrm{NaOH}$. This corresponded to zero time assay (blank); The remaining solution (substrate+enzyme) was incubated for $15 \mathrm{~min}$ at $37^{\circ} \mathrm{C}$ and then $0.5 \mathrm{ml}$ was drawn and mixed with 9.5 $\mathrm{ml}$ of $0.085 \mathrm{~N} \mathrm{NaOH}$. Absorbance was measured at 405 $\mathrm{nm}$ against the reference blank. Specific activities were expressed as $\mu$ moles of $\mathrm{p}$-nitrophenol formed per min per $\mathrm{g}$ tissue.

\section{Lipid peroxidation (LPO)}

LPO was estimated calorimetrically by measuring malondialdehyde (MDA) formation as described by Nwanjo and Ojiako (2005). In brief, $0.1 \mathrm{ml}$ of homogenate was treated with $2 \mathrm{ml}$ of a 1:1:1 ratio of TBA-TCA- $\mathrm{HCl}$ (TBA $0.37 \%$, TCA $15 \%, \mathrm{HCl} 0.25 \mathrm{~N}$ ) and placed in water bath at $65^{\circ} \mathrm{C}$ for $15 \mathrm{~min}$, cooled, and centrifuged at $5,000 \mathrm{rpm}$ for $10 \mathrm{~min}$ at room temperature. The optical density of the clear supernatant was measured at $535 \mathrm{~nm}$ against a reference blank. The MDA formed was calculated by using the molar extinction coefficient of thiobarbituric acid reactants (TBARS; $1.56 \times 10^{5} \mathrm{l} / \mathrm{mole} \mathrm{cm}^{-1}$ ). The product of LPO was expressed as nmol of MDA formed per $g$ of tissue.

\section{Blood and tissue lead determination}

For blood and liver wet tissue weight and volume of blood were recorded. After tissue digestion with concentrated $\mathrm{HNO}_{3}$ using a Microwave Digestion System (Model MDS, 2000), samples were brought to a constant volume and tissue lead content was determined following the procedure standardized in the laboratory according to the NOM-199-SSA1-2000 (Mushak and Crocetti, 1989) using an atomic absorption spectrophotometer (PerkinElmer Zeeman 5100).

\section{Histological studies}

Liver was dissected from the animals and fixed in buffered $10 \%$ formalin at room temperature for $72 \mathrm{~h}$. It was then thoroughly washed under running water and dehydrated in ascending grades of ethyl alcohol, cleared, and embedded in soft paraffin. Tissue sections of about $6 \mu \mathrm{m}$ were cut, stained with hematoxylin and eosin, and examined with a light microscope.

\section{Statistical analyis}

All data obtained from control and lead-poisoned animals were compared using student's t-test for unpaired means. A $p$ value $<0.05$ was considered significant.

\section{Results}

The MDA level of lead group was significantly higher than the control group values (Fig. 1). Significant reduction was observed in MDA concentration in vitamin $\mathrm{C}$ treatment group. These results show that vitamin $\mathrm{C}$ has a protective effect on hepatic oxidative. SOD, CAT and GSH activities (Tab. 1) in the liver of rats treated with lead acetate (group B) were significantly lowered compared with control rats (group 1) $(p<0.01)$, whereas administering vitamin $\mathrm{C}$ to lead acetate treated rats (group C) significantly elevated SOS, CAT and GSH activities compared to those animals on lead acetate treatment alone (group B). Tab. 2, revealed a significant augmentation in ALP and ACP activity $(p<0.01)$ in lead acetate group compared with the control group. However, ALP and ACP activity was markedly reduced in the group that received vitamin $\mathrm{C}(p<0.05)$.

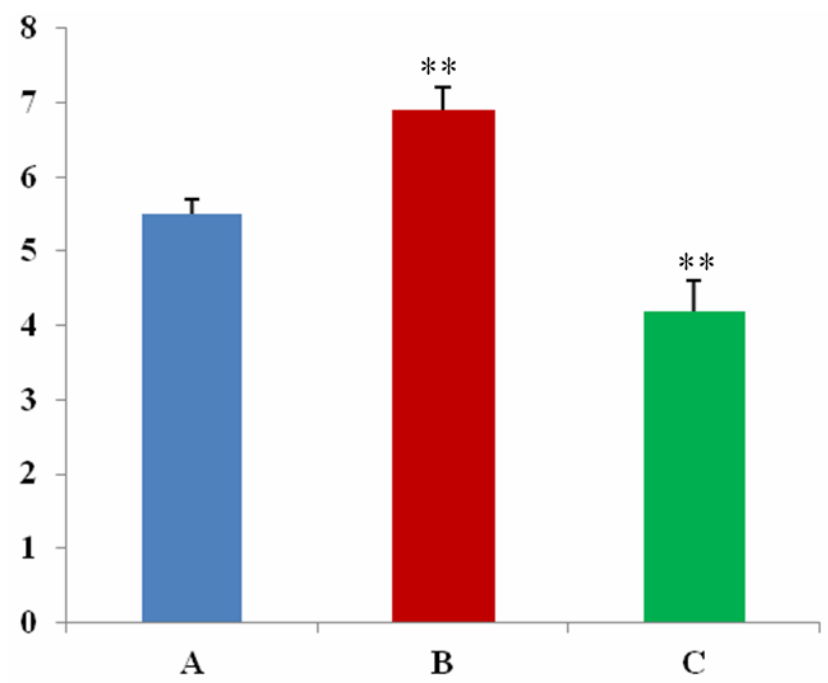

Fig. 1. Effect of lead acetate treatment ( 5 weeks) alone and in combination with vitamin C $(500 \mathrm{mg} / \mathrm{kg}$ b.w $)$ on the LPO levels in liver of rats. The values expressed as mean \pm SEM $(n=10)$. ${ }^{* * *} p<0.01$

Tab. 1. Protective effect of vitamin $C$ on hepatic oxidative stress related-parameters in lead acetate-exposed rat

\begin{tabular}{cccc}
\hline Parameter & A & B & C \\
\hline SOD & $5.39 \pm 0.5$ & $0.49 \pm 0.04^{* *}$ & $5.26 \pm 0.57^{*}$ \\
CAT & $58.69 \pm 5.64$ & $38.18 \pm 3.67^{* *}$ & $56.42 \pm 5.43^{*}$ \\
GSH & $11.20 \pm 1.07$ & $5.32 \pm 0.51^{* *}$ & $10.64 \pm 0.99^{* *}$ \\
\hline
\end{tabular}

Values are expressed as mean $\pm \mathrm{SD}$ for 10 rats in each group. ${ }^{*} p<0.05 ;{ }^{* *} p<0.01$. $\mathrm{SOD}\left(\mathrm{U} / \mathrm{ml}\right.$ of tissue extract); $\mathrm{CAT}$ ( $\mu$ moles of $\mathrm{H}_{2} \mathrm{O}_{2}$ degraded per min per mg protein); GSH (mg/g tissue) 
10

Tab. 2. Protective effect of vitamin $\mathrm{C}$ on hepatic biochemical parameters in rats

\begin{tabular}{cccc}
\hline Parameter & A & B & C \\
\hline ACP & $12.54 \pm 0.38$ & $37.22 \pm 0.76^{* *}$ & $24.21 \pm 0.76^{*}$ \\
\hline ALP & $17.91 \pm 0.71$ & $48.56 \pm 2.10^{* *}$ & $33.10 \pm 0.69^{*}$ \\
\hline
\end{tabular}

Values are expressed as mean \pm SD for 10 rats in each group. ${ }^{*} p<0.05 ;{ }^{* *} p<0.01$. ALP ( $\mu$ moles of $p$-nitrophenol formed per min per g of tissue; ACP ( $\mu$ moles of p-nitrophenol formed per min per $g$ of tissue)

Tab. 3. Lead concentration in the blood $[\mu \mathrm{g} / \mathrm{dL}$ and liver $(\mu \mathrm{g} / \mathrm{g})$ of rats]

\begin{tabular}{ccc}
\hline Group & Blood & Liver \\
\hline Control (A) & - & - \\
Lead acetate (B) & $40.5 \pm 2.3^{* * *}$ & $2.2 \pm 0.20^{* * *}$ \\
Lead acetate+ vitamin C (C) & $22.5 \pm 1.9^{* * *}$ & $1.9 \pm 0.30^{* * *}$ \\
\hline
\end{tabular}

The values expressed as mean \pm SEM $(\mathrm{n}=10) .{ }^{* * *} p<0.001$

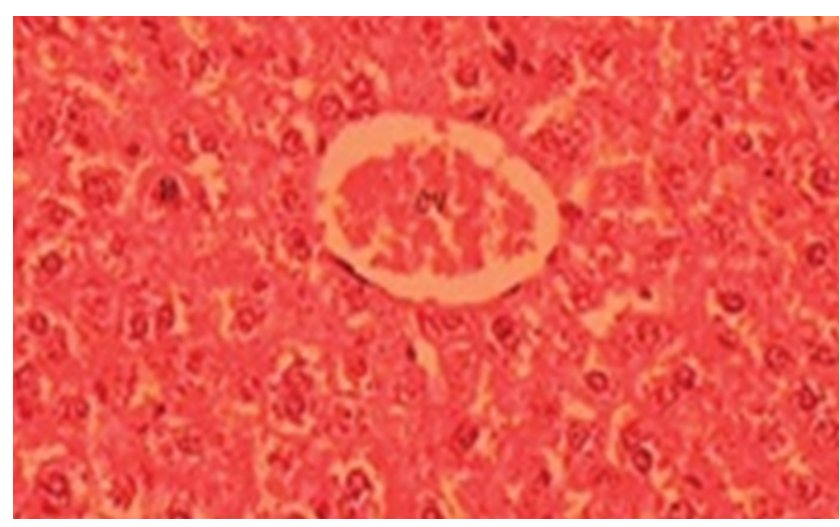

Fig. 2. Transverse section of the liver of a control rat showing hepatic cords arranged radially around the central vein and normal hepatocytes with centrally located nuclei

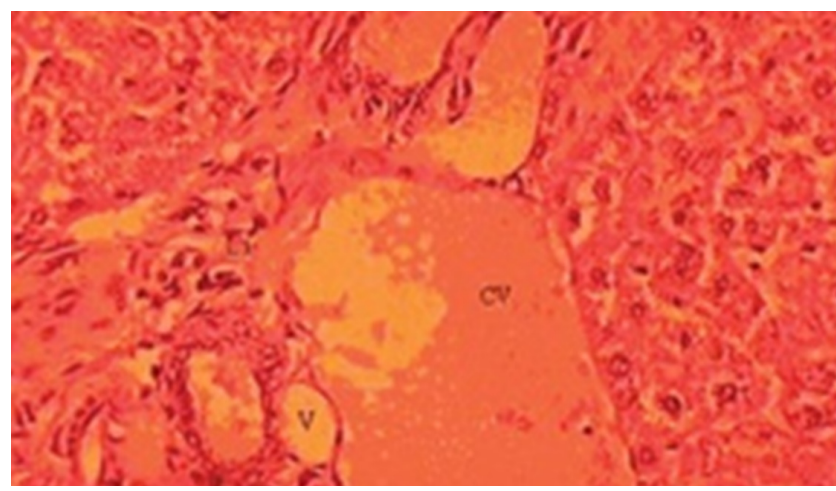

Fig. 3. Transverse section of the liver of a rat treated with lead acetate showing congestion of central vein, vacuolization, leucocytic infiltration, pyknotic nuclei, and loss of radial arrangement of hepatocytes

Lead exposure caused a significant increase in its levels in blood and liver samples compared with samples from controls (Tab. 3). Levels of lead in the blood and liver tissue increased significantly in the treatment group that was exposed to lead for 5 weeks. However, vitamin $\mathrm{C}$ treatment exposed animals, showed a significant $(p<0.001)$ decreased in the level of lea blood and liver as compared

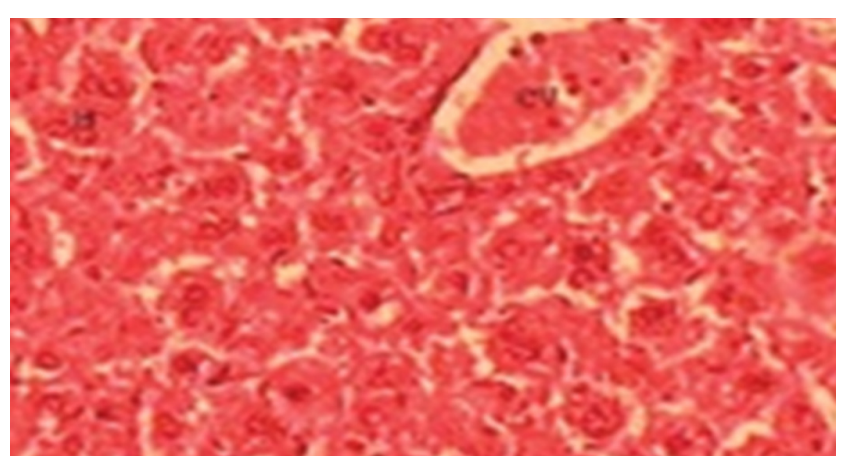

Fig. 4. Liver section obtained from a rat after treatment with lead acetate and vitamin c showing improvement of hepatic tissue

animals exposed to lead alone (Tab. 2). The data demonstrate that the vitamin $\mathrm{c}$ treatment was effective in mobilizing lead from blood and soft tissues. The liver of control rat showed normal hexagonadal or pentagonadal lobules with central veins and peripheral hepatic triads or tetrads embedded in connective tissue. Hepatocytes are arranged in trabecules running radially from the central vein and are separated by sinusoids containing Kupffer cells. They are regular and contain a large spheroidal nucleus (Fig. 2).

The livers of rat exposed to lead acetate for 5 weeks revealed disruption of the normal structural organization of the hepatic lobules and loss of the characteristic cordlike arrangement of the normal liver cells. The central and portal veins were congested. Many hepatic cells were damaged and lost their characteristic appearance while others showed marked cytoplasmic vacuolization. The nuclei of these cells were pyknotic. The central vein and sinusoids between hepatocytes were dilated. Some leukocyte infiltration and fatty deposition were also evident (Fig. 3). Animals treated with vitamin $\mathrm{c}$ showed that the majority of these histopathological changes were diminished. The liver restored most of its normal structure (Fig. 4).

\section{Discussion}

Lead is a wide spread constituent of earth's crust (Herbert, 1999). It can cause hypertension, developmental defects, neurological problems, renal dysfunction, and anemia. In recent years dietary vitamins with antioxidant property have been receiving considerable attention. It is believed that these vitamins can protect tissues against the damaging effect of free radicals (Osawa and Kato, 2005). The role played by natural compounds in the modulation of the toxic effects of lead acetate is little known. The present demonstrates the efficacy of vitamin $C$ in treating lead acetate toxicity. The present results indicate a significant alternation in the peroxidative process following lead acetate exposure. The increase in LPO level and decrease in the endogenous antixidant enzymes SOD, CAT, and GSH by lead acetate are consistent with earlier reports (Adanaylo and Oteiza, 1999; Mohammad et al., 2008). Cellular systems are well protected from ROS-induced cell injuries by an array of defenses composed of various antioxidants 
with different functions. Whenever the ROS present in the cellular system overpower these defense system, they cause oxidative stress or cell injury, leading to the development of diseases. It has been revealed that lead toxicity leads to free radical damage via two separate pathways: (1) the generation of ROS, including hydroperoxides, singlet oxygen, and hydrogen peroxide and (2) the direct depletion of antioxidant reserves (Ercal et al., 2001). The cell membrane is the main target of the oxidative damage produced by xenobiotics, including heavy metals (Halliwell and Gutteridge, 1989). This is mainly due to changes in polyunsaturated fatty acids having double bonds, largely present in the phospholipids of membranes (Slater, 1985). Lead is known to produce oxidative damage by enhancing peroxidation of membrane lipids, and LPO is a deleterious process carried out solely by free radicals. In fact, LPO is an outcome of the chain of events involving initiation, propagation, and termination reactions (Halliwell, 1996). Unchecked peroxidative decomposition of membrane lipids is catastrophic for living systems. The lipid peroxides produced are degraded into a variety of products, including alkanals, hydroxyl alkanals, ketones, and alkenes (Halliwell and Gutteridge, 1989). All these products inactivate cell constituents by oxidation or cause oxidative stress by undergoing radical chain reactions ultimately leading to loss of membrane integrity. LPO can also adversely affect the function of membrane-bound proteins, such as enzymes and receptors. Several studies have focused on the possible toxic effects of lead on membrane components and identified a correlation between these effects and lead-induced oxidative damage. Yiin and Lin (1995) demonstrated a marked enhancement in MDA concentration following incubation of linoic, linolenic, and arachidonic acd with lead. According to Caylak et al. (2007), lead might have a direct peroxidative activity or act indirectly by providing conditions suitable for LPO. Direct peroxidative activity of lead may be associted with ROS generation, such as $\mathrm{H}_{2} \mathrm{O}_{2}$, atomic opxygen, and hydroxyl radicals (Ding et al., 2000). Usually, the deleterious effects of oxidative stress are counteracted by endogenous antioxidant enzymes, mainly SOD, CAT, and GSH (Winterbourn, 1993). In the present study, the activities of SOS, CAT, and GSH antioxidants were reduced by lead acetate, thus exposing the tissues to peroxidative damage. CAT and SOD are metalloproteins accomplishing their antioxidant functions by enzymatically detoxifying peroxides $(-\mathrm{OOH}), \mathrm{H}_{2} \mathrm{O}_{2}$ and $\mathrm{O}_{2}$. These antioxidant enzymes depend on various essential trace elements and prosthetic groups for proper molecular structure and enzymatic activity. The pathogenesis of lead toxicity is multifactorial, as lead directly interrupts enzyme activation, competitively inhibits trace mineral absorption, and binds to sulfhydryl proteins (interrupting structural protein synthesis) (Slater, 1985). New findings revealed that GSH depletion is another important mechanism of lead toxicity. GSH is a tripeptide-containing cysteine with a reactive-SH group and reductive potency. GSH is an important cellular antioxidant defense system against freee radical overproduction, and decreasing its cellular concentration impairs cellular defenses against oxidative stress (Dickinson et al., 2003). It can act as a non-enzymatic antioxidant by direct interaction of the $-\mathrm{SH}$ group ROS, or it as a can be involved in the enzymatic detoxification reactions for ROS as a cofactor or a coenzyme (Gürer $e t$ al., 1998). It possesses carboxylic acid groups, an amino group, a-SH group, and two peptide linkages as sites for reactions of metals. Lead binds exclusively to the $-\mathrm{SH}$ group, which decreases the GSH levels and can interfere with the antioxidant activity of GSH (Bechara, 2004). Liver enzymes such as ACP and ALP are marker enzymes for liver function and integrity (Adaramoye et al., 2008). These enzymes are usually elevated in acute hepatotoxicity or mild hepato-cellular injury, but tend to decrease with prolonged intoxication due to liver damage (Cornelius, 1979). In the present study, administration of lead acetate led to a significant rise in total ACP, and ALP activities. These results are in accordance with our previous findings (Sharma et al., 2009). Administration of lead acetate causes assimilation of fat in the liver, leading to increased ACP activity. This may be also due to the lysosomal imbalance resulting in the destruction of the intact membranes (Abraham and Wilfred, 2000). ALP has been reported to be the marker enzyme for plasma membrane (Wright and Plummer, 1974) and is required in certain amounts for proper functioning of organs (Brain and Kay, 1927). Increase in the ACP and ALP activities indicated the increased permeability, damage, and/or necrosis of cells (Raquel et al., 1997).

We observed that lead exposure produced pronounced hepatic histopathology evidenced by histological alternations in liver, including focal necrosis with hepatocyte vacuolization and swelling, pyknotic nuclei, and dilation of central vein and sinusoids. These findings are in support with Shalan et al. (2005). In accordance with the present findings, El Sokkary et al. (2005) also showed that liver of lead-treated rats revealed remarkable degenerative alterations. Lead hepatotoxicity led to vacuolization of the cells, polymorphism of the nuclei, and decrease in glycogen content of the hepatocytes (Foulkes, 1996; Pereira et al., 2001). Antioxidant vitamins are reported to provide protection against free radical damage in the body through their antioxidant activities (Dakshinamuti and Dakshinamuti, 2001). It was found that levels of liver marker enzymes (ACP and ALP) were decreased significantly by traetment with vitamin $\mathrm{C}$. The observed decrease in these enzymes showed that vitamin $C$ preserves the structural integrity of the tissues from the toxic effect of lead acetate (Adaramoye et al., 2008; Jens and Hanne, 2002). Results from the present investigation also revealed that the use of vitamin $\mathrm{C}$ along with lead acetate can reduce lead accumulation in tissue. Although one of the major drawbacks of lead mobilization is its redistribution from bone to other critical tissues (Marcus, 1985; Wittmers et al., 1988); we 
12

did not observe an increase in the levels of lead in blood and liver tissues after Vitamin $\mathrm{C}$ treatment when they were compared with their respective positive controls. This suggests that vitamin $\mathrm{C}$ can affect lead toxicokinetics in rats in a useful way. The high concentration of lead in blood and liver tissues has been associated with oxidative stress, which might be responsible, at least in part, for lead's toxic effects. vitamin $\mathrm{C}$ produced protective effects on histological structure of the liver against lead toxicity. When vitamin $\mathrm{C}$ was administered with lead, the liver retained its normal architecture and was also able to diminish fibrosis, congestion, and hepatocyte vacuolation. These results are in accordance with Shalan et al. (2005) to some extent.

\section{Conclusions}

The present study showed that vitamin $\mathrm{C}$ treatment partly mitigates lead acetate-induced changes in hepatochemical parameters. This could be due to its antioxidant nature, which combines free radical

Scavenging with metal chelating properties. The healing effect of vitamin $\mathrm{C}$ was also confirmed by histological observations, which suggest that the vitamin $\mathrm{C}$ was effective in bringing about functional improvement of hepatocytes. Vitamin C can be given as a dietary supplement to human populations exposed to environmental toxicants and can provide protection against toxic effects. Moreover, efforts are needed for the choice of appropriate dose, duration of treatment, and possible side-effects on major organs.

\section{References}

Aboul-Enein AM, Abou-Elella FN, Abdullah ES (2010). Monitoring of some organochlorines and organophosphorus residues in imported and locally raised chicken and bovine muscles in Egypt. J Appl Sci Res 6(6):600-608.

Abraham P, Wilfred G (2000). Lysosomal enzymes in the pathogenesis of carbon tetrachloride induced injury to the testis and the rat. Ind J Pharmacol 32:250-251.

Adanaylo VN, Oteiza PI (1999). Lead intoxication: antioxidant defenses and oxidative damage in rat brain. Toxicology 135: 77-85.

Adaramoye OA, Osaimoje DO, Akinsanya MA, Nneji CM, Fafunso MA, Ademowo OG (2008). Changes in antioxidant status and biochemical indices after acute administration of artemether, artemether-lumefantrine and halofantrine in rats. Basic Clin Pharmacol Toxicol 102:412-418.

Aebi HE (1993). Catalase, 273-286 p. In: Bergmeyer HU, Bergmeyer J, Grabl M (Eds.). Methods of enzymatic analysis. Vol. 3. Velag Chemie Gmbh, Weinheim.

Afify AMR, El-Beltagi HS (2011). Effect of the insecticide cyanophos on liver function in adult male rats. Fresen Environ Bull 20(4a):1084-1088.

Baht RV, Moy GG (1997). Monitoring and assessment of di- etary exposure to chemical contaminants. Who, Geneva, $132-149 \mathrm{p}$.

Bechara EJH (2004). Lead poisoning and oxidative stress. Free Radic Biol Med 36:S22.

Brain RI, Kay KO (1927). Kidney phosphatase II: the enzyme in disease. Biochem J 21:1104-1108.

Caylak E, Halifeoiglu I, Aydin S, Telo S, Bulmus O, Celik H (2007). The effects of sulfur-containing compounds on total antioxidant capacity levels of liver, kidney and brain in leadexposed rats. Turkiye Klinikleri J Med Sci 27:823-828.

Cornelius CE (1979). Biochemical evaluation of hepatic function in dogs. J Am Anim Hosp Assoc 15:25-29.

Correia PRM, Oliveira E, Oliveira PV (2000). Simultaneous determination of $\mathrm{Cd}$ and $\mathrm{Pb}$ in foodstuffs by elecro thermal atomic absorption spectrometry. Analyt Acta 405:405-211.

Dakshinamuti K, Dakshinamut S (2001). Blood pressure regulation and micronutrients. Nutr Res Rev 14:3-43.

Dickinson DA, Moellering DR, Illes KE, Patel RP, Levonen AL, Wigley A, Darley-Usmar VM, Forman HJ (2003). Cytoprotection against oxidative stress and the regulation of glutathione synthesis. Biol Chem 384:527-537.

Ding Y, Gonick HC, Vaziri ND (2000). Lead promotes hydroxyl radical generation and lipid peroxidation in cultured aortic endothelial cells. Hypertens 13:552-555.

Duruibe JO, Ogwuegbu M.C, Egwurugwu GN (2007). Heavy metal pollution and human biotoxic effects. Int J Phys Sci 2(5):112-118.

El-Beltagi HES, Salama ZA, El-Hariri DM (2008). Some biochemical markers for evaluation of flax cultivars under salt stress conditions. J Nat Fiber 5(4):316-330.

El-Beltagi HS, Ahmed OK, El-Desouky W (2011). Effect of low doses $\gamma$-irradiation on oxidative stress and secondary metabolites production of Rosemary (Rosmarinus officinalis L.) callus culture. Radiat Phys Chem 80(9):965-973.

El-Beltagi HS, Mohamed AA (2010). Changes in non-protein thiols, some antioxidant enzymes activity and ultrastructural alteration in radish plant (Raphanus sativus L.) grown under lead toxicity. Not Bot Horti Agrobo 38(3):76-85.

El Sokkary GH, Abdel-Rahman GH, Kamel ES (2005). Melatonin protects against lead induced hepatic and renal toxicity in male rats. Toxicology 231:25-33.

Ellman GC (1959). Tissue sulfhydryl groups. Arch Biochem Biophys 82:70-77.

Ercal N, Gurer-Orthan H, Aykin-Burns N (2001). Toxic metals and oxidative sress. Part 1 . Mechanisms involved in metalinduced oxidative damage. Curr Top Med Chem 1:529-39.

Foulkes EC (1996). Metals and biological membranes, 133143 p. In: Chang L (Ed.). Toxicology of metal. Boca Raton, CRC, Florida.

Gürer H, Ercal N (2000). Can antioxidant be beneficial in the treatment of lead poisoning? Free Radic Biol Med 29:927945. 
Gürer H, Ozgunes H, Neal R, Spitzand DR, Ercal N (1998). Antioxidant effects of $\mathrm{N}$-acetyle cystein and succimer in red blood cells from lead exposed rats. Toxicology 128:181189.

Halliwel B (1996). Mechanisms involved in the generation of free radicals. Pathol Biol 44:6-13.

Halliwell B, Gutteridge JMC (1989). Free radicals in biology and medicine. Clarendon, Oxford.

Hayes WJ, Laws RR (1991). Handbook of pesticide toxicology. Academic Press, Inc., Harcourt Brace Jevanovich Publisher. San Diego, New York and Tokyo.

Herbert LN (1999). History of lead poisoning in the world, 1725 p. In: Abraham MG (Ed). Proc of International Conference on Lead Poisoning, Prevention and Treatment.

Jens JJ, Hanne H (2002). A review on liver function test. The Danish hepatitis C. Retrieved from: http//home3.inet.tele. $\mathrm{dk} /$ omni/hemochromat osis_iron.htm.

Malecka A, Jarmuszkiewicz W, Tomaszewska B (2001). Antioxidative defense to lead stress in sub cellular compartments of pea root cells. Acta Biochim Pol 48:687-698.

Marcus H (1985). Multicompartment kinetic models for lead. 1. Bone diffusion models for long-term retention. Environ Res 36(2):441-458.

Marklund S, Marklund G (1974). Involvement of superoxide anion radical in the autooxidation of pyrogallol and convenient assay for SOD. Eur J Biochem 47:469-74.

Meyer SA, Kulkarni AP (2001). Hepatotoxicity, 487 p. In: Introduction to biochemical toxicology. $3^{\text {rd }}$ Edn. John Wiley and Sons, NY.

Mohamed AA, El-Beltagi HS, Rashed MM (2009). Cadmium stress induced change in some hydrolytic enzymes, free radical formation and ultrastructural disorders in radish plant. Electron J Environ Agric Food Chem 8(10):967-983.

Mohammad IK, Mahdi AA, Raviraja A, Najmul I, Iqbal A, Thuppil V (2008). Oxidative stress in painters exposed to low lead levels. Arh Hig Rada Toksikol 59:161-169.

Nwanjo HU, Ojiako OA (2005). Effect of vitamins E and C on exercise induced oxidative stress. Glob J Pure Appl Sci 12:199-202.

Omaya ST (2004). Introduction to food toxicology, 1-26 p. In: Waston D (Ed.). Pesticides, veterinary and other chemical residues in food. Woodhead Publishing Ltd, Cambridge.
Osawa T, Kato Y (2005). Protective role of antioxidative food factors in oxidative stress caused by hyperglycemia. Ann NY Acad Sci 1043:440-451.

Pereira R, Pereira ML, Ribeiro R, Goncalves F (2001). Wildlife animals as sentinels to human health due to environmental exposure to heavy metals. In: Abstract Book. Proc of the $11^{\text {th }}$ Annual Meeting of Europe Society Environmental Toxicology and Chemistry, Madrid.

Raquel ES, Ines AG, Juan LC (1997). Lead effects on structural and functional cellular parameters in human red cells from a prenatal hematopoiesis stage. Biometals 10:331-335.

Sadashivam S, Manickam A (1996). Biochemical methods. India 2:121-124.

Shalan MG, Mostafa MS, Hassouna MM, El-Nabi SE, El-Refaie A (2005). Amelioration of lead toxicity on rat liver with vitamin C and silymarin supplements. Toxicology 206: 1-15.

Sharma A, Sharma V, Kansal L (2009). Therapeutic effect of Allium sativum on lead-induced biochemical changes in soft tissues of Swiss albino mice. Phog Mag 5:364-371.

Slater TS (1985). Free radical mechanism in tissue injury. Biochem J 222:1-25.

Winterbourn CC (1993). Superoxide as an intracellular sink. Free Radic Biol Med 14:85-90.

Wise RR, Naylor AW (1987). Chilling-enhanced peroxidation: the peroxidative destruction of lipids during chilling injury to photosynthesis and ultrastucture. Plant Physiol 83:227272.

Wittmers LE, Wallgren J, Alich A, Aufderheide AC, Rapp G (1988). Lead in bone. Distribution of lead in the human skeleton. Arch Environ Health 43(6):381-391.

Wright PJ, Plummer DT (1974). The use of urinary enzyme measurement to detect renal damage caused by nephritic compounds. Biochem Pharmacol 21:65-73.

Xienia U, Foote GC, Van S, Devreotes PN, Alexander S, Alexander H (2000). Differential developmental expression and cell type specificity of Dictyostelium catalases and their response to oxidative stress and UV light. Biochim Biophys Acta 1492:295-310.

Yiin SJ, Lin TH (1995). Lead-catalyzed peroxidation of essential unsaturated fatty acid. Biol Trace Elem Res 50:167-172. 